\title{
Evaluation of DNA conservation in Nile-Saharan environment, Missiminia, in Nubia: Tracking maternal lineage of "X-Group".
}

\author{
Yahia Mehdi Seddik CHERIFI $^{\mathrm{a}, *}$, Selma AMRANI ${ }^{\mathrm{b}}$ \\ ${ }^{a}$ Archeology, Laboratoire d'Anthropometrie, du Patrimoine et d'Archeologie \\ (LAPA), Bouzareha, Algiers, Algeria \\ ${ }^{b}$ Institute of Archeology, University of Algiers 2, Bouzareha, Algiers, Algeria
}

\begin{abstract}
Objective: We assessed DNA conservation using a range of archaeological skeletal samples from Sudan (Missiminia in Upper Nubia, 350 B.C.E to 1400 C.E) from the unfavorable conditions of the Saharan milieu and humidity of the Nile valley by tracking maternal lineage on the 'X-Group' (Ballaneans).

Method: We were able to extract, amplify, and sequence mt-DNA HVS-I (Sanger sequencing method) from 11 petrous bone samples, eight for the X-Group set and three for the reference set (one Christian, one Late Meroitic, and one Meroitic).

Results: It was possible to find the haplogroups (L1b, L2, L3, H2, N, T1a, X and W) and to carry out comparative data analysis in relation to haplogroup data cited in the literature. This investigation into the maternal lineage of X-Group (350 to 500 C.E.) origins allowed us to validate the efficiency of petrous bone sampling from ancient human remains from the Nile-Saharan milieu and established that the Ballaneans experienced an in-situ development with more admixture from the Levant region and North Africa.

Conclusions: Our study used mt-DNA (HVS-I) to look for the biological origins of the XGroup from Upper-Nubia and demonstrated the feasibility of ancient DNA research on skeletons from the Nile-Saharan environment. The use of Next Sequencing Generation (NGS) should optimize and improve the detection of shorter DNA strands and their sequencing in complete genomes from ancient skeletal remains (petrous bones) from hot and humid environments.
\end{abstract}

Keywords: ancient DNA, North-Africa, Sudan, mitochandrial DNA, DNA preservation, paleogenetics, post-Meroitic

\section{BACKGROUND}

Archaeological samples, mostly bones and teeth, withstand the damaging outcomes of time and the environment and preserve the DNA within them. Recovering DNA from these

\footnotetext{
*Corresponding author.

Email addresses: mehdi.cherifi@gmail.com (Yahia Mehdi Seddik CHERIFI), amrani.selma@gmail.com (Selma AMRANI)
} 
surviving materials is influenced by numerous factors (Supplementary Figure 1S): experimental procedures [1-3], type of sample [4-6], taphonomy [6, 7], and climatic conditions [810]. However, not all elements having an impact on ancient DNA (aDNA) preservation and amplification are completely understood and are mainly dependent, as in previous observations [5], on environmental factors rather than on sample age [11, 12]. Here, we assessed DNA preservation using a range of archaeological skeletal samples from Sudan (Missiminia in Upper Nubia, 350 B.C.E. to 1400 C.E.).

\section{Ancient DNA studies in Nubia}

The Nile valley of Sudanese Nubia is often considered as an incredibly rich and various archaeologically, although there are few investigations of aDNA in Nubia [13-15]. Themain aim of this study was to optimize the methodology and chances of successful sampling in Saharan environments. Paleogeneticists could address many important questions in the Nile valley, using aDNA analysis to seek the origin of the resident population and its evolution in relation to genetic and cultural admixture. Questions have been raised about the diversity of the population of Nubia because of its rich historical background, with its succession of three phases of Egyptian conquests, kingdoms and chiefdoms, and the constant pressure of desert tribes on the valley settlers.

While no proper anthropological storage facility or study was ever established in Nubia, most cranial materials were collected and transferred to the countries concerned with survey excavations: England, France, Denmark, and the United States [16-18]. Consequently, it is not unexpected that throughout the literature only three attempts to use aDNA from Sudanese Nubia have been published [13-15]. Fox (1997) [13] worked on Meroitic samples from Amir Abdellah (near Abri) using mitochondrial marker Hpa1 $(n p 3,592)$ and suggesting sub-Saharan admixture. Francigny et al. (2013) [14] used teeth from four Nubian samples from different periods and archaeological contexts that succeeded in one amplification PCR (Christian); however, the typing autosomal STR is not confirmed. Sirak et al. (2014) [15] have worked on mt-DNA that highlighted only one sample (Christian), belonging to haplogroup L5, in favor of sub-Saharan admixture and confirming that aDNA could beanalyzed on samples from Saharan or sub-Saharan environments. Some articles were focused on the effect of military expeditions during the period of antiquity $[19,20]$ and others on genetic admixture pertaining to the Nubian corridor [21].

From ancient skeletal specimens, the success of DNA extraction and its reliability are complicated by degradation and contamination. For bone, local hydrology, $\mathrm{pH}$, water content, oxygen levels, and soil composition have been identified as essential environmental parameters, contributing to the time period for the integrity of the material [22]. For DNA, temperature is considered an essential element before $\mathrm{pH}$, soil content (salinity), and water content [23].

\section{Archaeological context}

The Franco-Sudanese team, led by Andre Vila and the Khartoum National Museum, carried out five excavation campaigns in the years 1972 to 1975, enabling the archaeological sites to be surveyed along the Nile valley in Upper Nubia, along a length of 
$63 \mathrm{~km}$, between the Dal cataract and the island of Nilwatti (Figure 1).

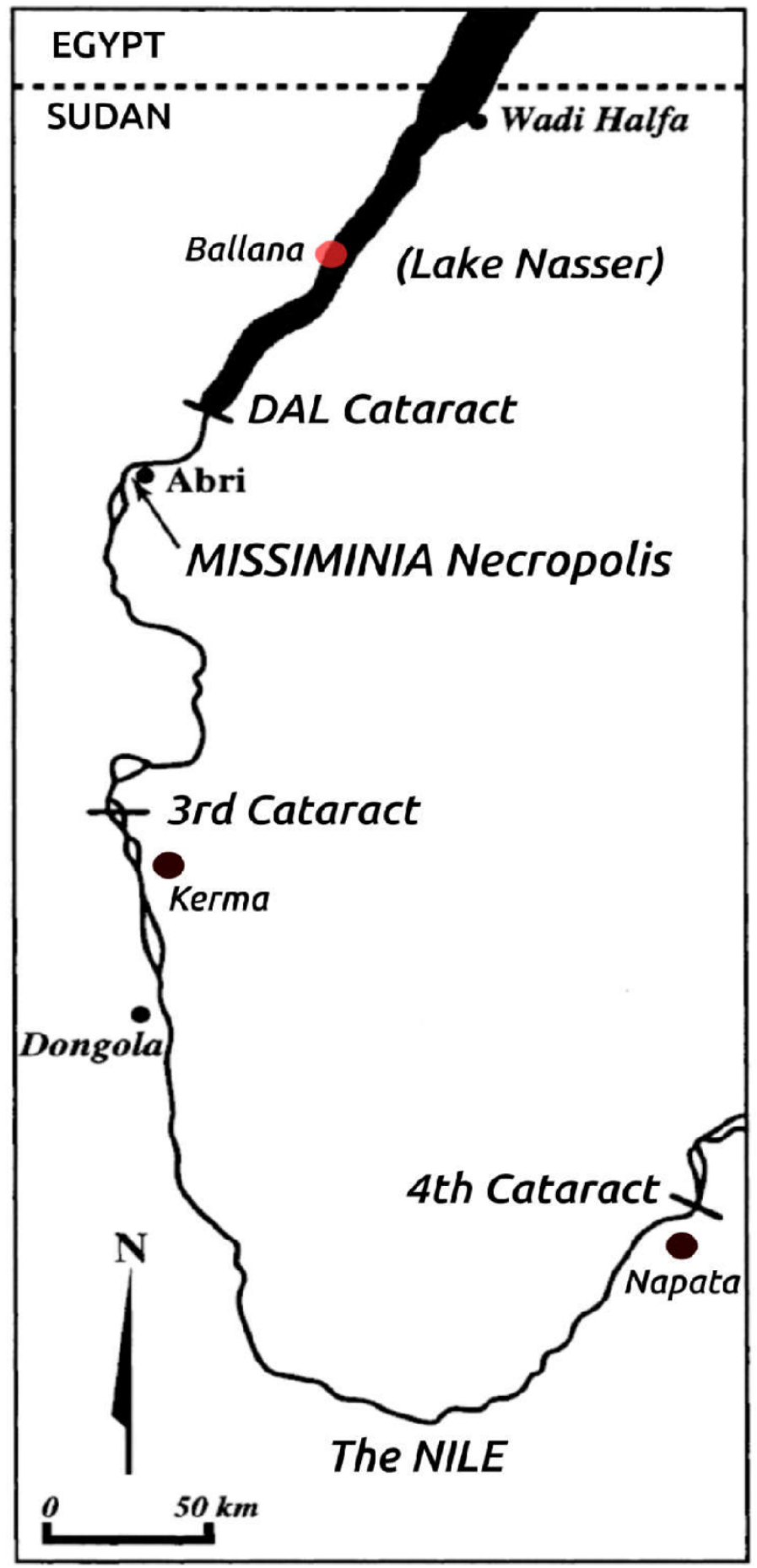

Figure 1: Missiminia necropolis, is located along the Nile valley in Upper Nubia (Sudan),from200 km south of Wadi-Halfa, after the DAL cataract in the Abri district.

Important osteological material was collected and transferred to Limoges (France) for study in the laboratory during the year 1979. It consisted of 379 skulls and 346 mandibles, 
coming almost exclusively from the Missiminia Necropolis, which constitutes a funeral ensemble of $950 \mathrm{~m}$ in length by $100 \mathrm{~m}$ in width, about 700 meters south of the Abri's souk (Figure 2). The major interest in this cranial collection is undoubtedly linked to the geographical situation of the necropolis in Sudanese Nubia, $200 \mathrm{~km}$ south of Wadi-Halfa (Figure 1). It is, in fact, the post-Pharaonic complex closest to the cultural centers of Napata and Meroe between the 3rd and 4th cataracts which were poor in terms of skeletal remains.

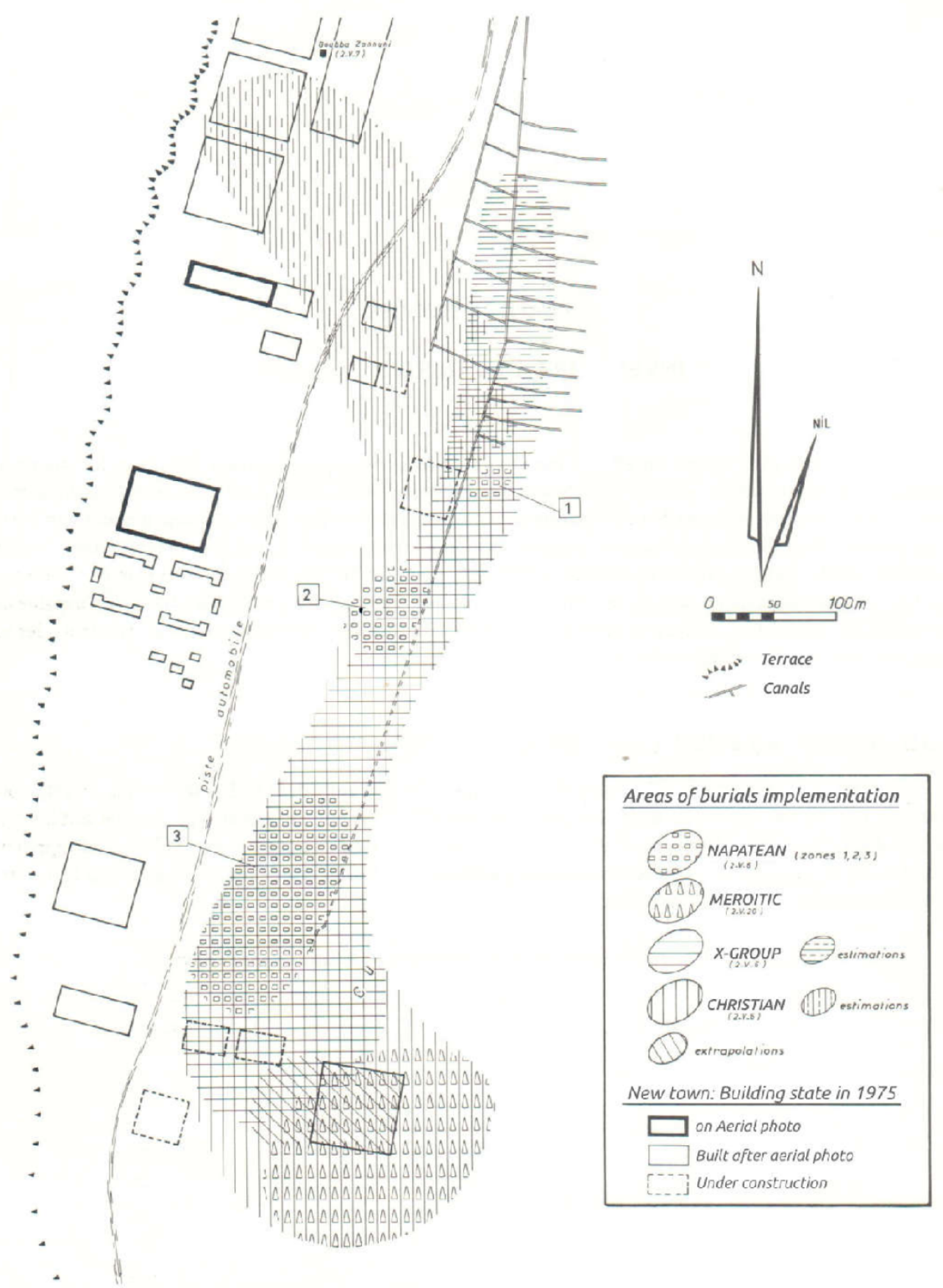

Figure 2: The areas of distribution of burials according to the different cultural phases and construction in progress of the new town of Abri-Missiminia (A.Vila of 1980). 
At Missiminia, the proportion of skulls and mandibles in good macroscopic condition varied greatly, according to the cultural phase concerned: Napatean tombs with one subject out of 146 subjects (subjects from multiply used tombs, 16 pre-Meroitic samples studied came from other sites); Meroitic tombs and intrusive sepulchers (named "late Meroitic") with 266 subjects out of 486 subjects; Ballanean Tombs (X-Group) with 56 subjects (54 skulls and 53 mandibles) out of 255 subjects from the graves of necropolis 2-V-6, except for one from 8-B-34 (cemetery of El Behel) near the Dal cataract; and Christian and undetermined graves with 91 subjects out of 269 subjects [24].

The causes of destruction are chiefly due to the action of moisture, depending on whether the tombs occupied the bed or, on the contrary, the banks of an old Nile arm, which also subjected them to exceptional floods. This is the case of the Napatean tombs and part of the Ballanean (X-Group) and Christian tombs, where the bones had become weak, if not powdered [17,24].

Another cause is the plundering of the graves, causing the disintegration of the skeletons and breaking of the bones. But sometimes the upheaval and dispersal of the human remains resulted in a better conservation, as they were bathed in a sterile and desiccant environment: wind-borne sand. This was the case with the Meroitic tombs, used several times [24].

\section{About ' $X$-Group'}

The term X-Group Culture was used for lack of a more exact historical definition by George A. Reisner, who first discovered this civilization [25]. At Missiminia, the X-Group burial stretched through the length of the necropolis, on a strip of 300 by 80 meters (Figure 2). X-Group is known to be post-Meroitic, 350 to 550 C.E (Figure 3), associated with Ballanean Culture 300 to 600 C.E $[17,24,26-28]$ due to their cultural changes, such as not using the Meroitic language, use of barrows in funeral practices, and ceramic innovation linked to Ballana [29]. These changes were accompanied by morphological variations [29, 30], and were based on an agrarian mode with a likely herding economy and isolated 'Mediterranean break' [31,32]. Some included large barrows (between 5 and $20 \mathrm{~m}$ in diameter) which were to be those of persons who were to have, if not power, at least a certain social primacy. They can be considered true central sites [17, 29].

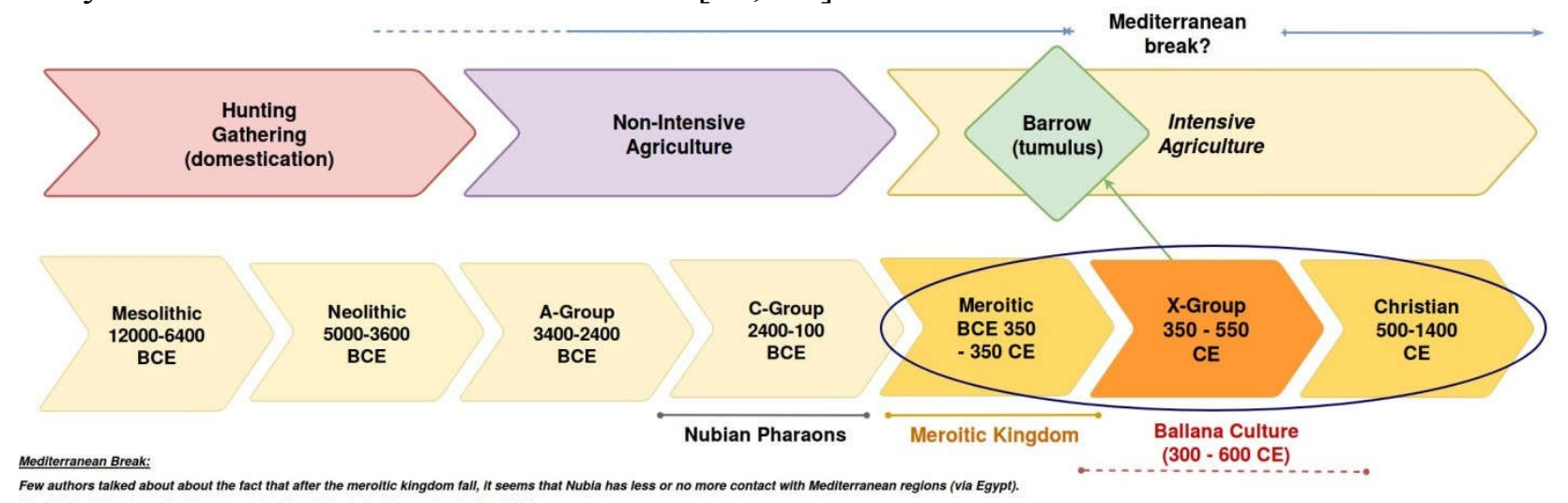

Was that a choice from the Roman empire? (no historical evidence found about this).

Figure 3: The Nubian population, had known seven specific periods of occupation or three broad phases spanning from the Mesolithic through the Christian era. Within the blue ellipse is our study area of interest, the main target being the X-Group. 
The X-Group remains questionable and could be solved through aDNA. About their origins, there are two conflicting hypotheses or assumptions:

1. Outlier income: new people were associated with gene flow from both sub-Saharan and Mediterranean sources [17, 24, 29, 33-38].

2. In-situ: local people with genetic micro-evolution [13, 19, 20, 39]. A variation coming from a more open model of society is also proposed [15, 18, 29].

We conducted a study on 15 samples (petrous bones) from the Nubia, Missiminia necropolis to further investigate the following questions. These questions are essential for the optimized analysis of aDNA originating from a Nile-Saharan biotope:

- Is it possible to obtain a well-conserved aDNA from petrous bones from hot environments which are unfavorable for aDNA preservation?

- Are there differences between sampling on free and fixed petrous bone and the cranium $[40]$ ?

- Through maternal lineage determination, what is the history of the maternal part of the X-Group origins?

\section{MATERIALS AND METHODS}

All laboratory work was performed in the dedicated clean laboratory facilities at the Laboratory AMIS UMR 5288, University of Paul Sabatier — Toulouse III, according to strict aDNA standards [41, 42].

\section{Materials}

The specimens reported in this study were skulls recovered during excavations at the Missiminia necropolis and studied osteologically. An exhaustive osteometric study was carried out by Billy, a brief odontological study by Verger-Pratoucy, and another brief paleopathological study by Dastugue [24], and a complete study was carried out on discrete cranial traits [17].

From the X-Group, 13 samples were selected and three other samples that occupied the Missiminia necropolis were added, one from each of the main groups (Table 1): Meroitic, Late Meroitic, and Christian (see ellipse in Figure 3). These served as the reference set to evaluate a difference in DNA preservation between these groups and the X-Group.

Criteria for selecting the samples were primarily and consecutively: good specimens by visual and tactile inspection (scored as bad, average, or good), specimens having petrous bones (at least one), specimens (X-Group) found in a barrow (tumulus), and specimens, mainly X-Group, that could be related, or were at least reported as one set from previous studies [17]. Only four sample had a free petrous bone; the 12 others had the petrous bone fixed on the skull. Table 1 provides more details on the petrous samples.

(Here is Table 1) 


\section{Methods}

\section{Authenticity criteria}

Different precautions have been observed to reduce contamination with modern DNA. These include preserving the strict sterile conditions, minimizing the number of individuals handling the specimens, and determining the mitochondrial DNA polymorphism pattern of the researchers who had the direct contact with the specimens, as presented in Supplementary Table S1. Adherence to the best practice procedures for working with aDNA [43] was strictly maintained.

\section{Sampling}

To reduce the possibilities of contamination by modern DNA through handling, the sampling manipulations (cleaning and grinding) were performed by a single person wearing a full body suit dedicated to this task. The sampling of the specimens, previously irradiated by UV, was carried out in a specific room within a ductless fume hood. To further avoid contamination, all tools used were UV decontaminated within a Cross-Linker, and gloves were changed at key times.

The sampling protocol was adapted to the specimen. Thus, for free petrous bone or those originally fixed then detached using the Dremel (four cases), this included: pre-cleaning, abrasive cleaning of the surfaces before cutting (these two operations were carried out with a tool (Argofile MAXIMA PHP40 set, Japan), which can be fitted with forgers or saws depending on the needs), and harvesting into $5 \mathrm{ml}$ tubes filled by a minimum of $300 \mathrm{mg}$ of the bone powder [40]. The petrous bone attached to the skull was subjected to pre-cleaning (removing all contents of the cranial box), abrasive cleaning of the surfaces, drilling with Dremel 3000, and harvesting of the bone powder into $5 \mathrm{ml}$ tubes filled by a minimum of 300 $\mathrm{mg}$ of the bone powder.

\section{DNA operations}

All aDNA manipulations were conducted in a dedicated aDNA facility with laminar flow hoods equipped with HEPA air filtration and inner UV light systems (one hood for DNA extraction, another for PCR setup).

Digestion. The lysis buffer, $555 \mu \mathrm{l}$, containing $500 \mu \mathrm{l}$ of EDTA $(0.45 \mathrm{M}), 50 \mu \mathrm{l}$ of Proteinase $\mathrm{K}(2 \mathrm{mg} / \mathrm{ml})$ and of $5 \mu \mathrm{l}$ DTT $(10 \mathrm{mM})$, was added to a $2 \mathrm{ml}$ tube with $200-300 \mathrm{mg}$ bone powder. Digestion was done overnight at $50^{\circ} \mathrm{C}$ with agitation (Specimix). Blank controls were used with each extraction series.

DNA Extraction. Any powder left was conserved into a plastic bag at $-20^{\circ} \mathrm{C}$ and the supernatant was kept in the $5 \mathrm{ml}$ tube and $2.5 \mathrm{ml}$ binding buffer was added. The mixture, $600 \mu \mathrm{l}$, was added to a Qiagen Minelute Column, centrifuged $1 \mathrm{~min}$ at $8.000 \mathrm{rpm}$ and the flow-through was discarded. This operation was repeated on the remaining mixture for each $600 \mu \mathrm{l}$ and finally was rinsed by $600 \mu \mathrm{l}$ wash buffer PE, centrifuged $1 \mathrm{~min}$ at $11.000 \mathrm{rpm}$, the flow-through was discarded, and the remainder was centrifuged 1 min again at 11.000 rpm to remove all the ethanol. DNA was eluted in $40 \mu$ l Elution Buffer Kit Minelute Qiagen and $0.05 \%$ Tween, preheated at $37^{\circ} \mathrm{C}$. It was incubated for $5 \mathrm{~min}$ at room temperature, and then centrifuged for $2 \mathrm{~min}$ at $13.000 \mathrm{rpm}$. Extracted DNA was stored at $-20^{\circ} \mathrm{C}$.

Amplification of DNA and mt-DNA Sequencing Amplification of DNA. Considering the enormous capacity of PCR (Polymerase Chain Re- 
action) to amplify even a few copies of DNA sequences, modern DNA contamination has become a crucial problem. Another difficulty is the production of sufficient quantities of authentic DNA sequences to make a study conclusive, due to post-mortem DNA degradation processes (Supplementary Figure 1S) causing miscoding lesions potentially leading to sequence errors, thus raising the risk for preferential amplification of exogenous contaminant sequences.

To deal with this issue, we followed criteria authentication and adopted the use of four primerpairs, Mini-Primersetmt-DNA, to amplify the HVS-1 region in overlapping segments 146-165 bpinlengthasdescribedin [44]. Blankcontrols were usedtodetectcontamination, and positive controls (other ancient samples) were used to establish the effectivity of PCR set up in isolation from aDNA.

Amplification was carried out in a $25 \mu \mathrm{l}$ final volume PCR tube containing $23 \mu \mathrm{l}$ of the PCR mix (0.2 mM dNTP, $1.5 \mathrm{mM} \mathrm{MgCl} 2,0.2 \mathrm{mg} / \mathrm{ml}$ BSA, Buffer 1X (Gold ST*R 10X Buffer (Promega, Madison, WI)), primers at $600 \mathrm{nM}$ and 2.5U AmpliTaq Gold DNA Polymerase (Applied Biosystems, Foster City, CA)) and $2 \mu \mathrm{l}$ of aDNA (for samples and positive controls) or water for PCR negative controls. After an initial $11 \mathrm{~min}$ at $95^{\circ} \mathrm{C}$ to denature DNA double strands, 40 cycles were done as follows: $95^{\circ} \mathrm{C}$ for 20 seconds, $50^{\circ} \mathrm{C}$ for 20 seconds, $72^{\circ} \mathrm{C}$ for 30 and final elongation step of $72^{\circ} \mathrm{C}$ for seven minutes. PCR products were visualized on a $2 \%$ Agarose gel.

Mt-DNA Sequencing. All PCR products, before sequencing, were purified using QIA quick PCR Purification Kit (Qiagen, Hilden, Germany) or were cleaned using a standard Exo-SAP protocol $\left(5 \mu \mathrm{l} \mathrm{PCR}\right.$ product and $1 \mu \mathrm{l}$ of Exo-SAP, $30 \mathrm{~min}$ at $\left.37^{\circ} \mathrm{C} / 20 \mathrm{~min} 80^{\circ} \mathrm{C}\right)$. Sequencing reactions were carried out on 96-well plates using BigDye Terminator v3.1 Cycle Sequencing Ready Reaction Kit (Applied Biosystems, foster City, CA) for 30 cycles, as follows: $95^{\circ} \mathrm{C}$ for 10 seconds, $50^{\circ} \mathrm{C}$ for five seconds, $60^{\circ} \mathrm{C}$ for two minutes. Sanger sequencing was run at Genopole Toulouse (France) on an ABI3730 Genetic Analyzer (Applied Biosystems).

Data analysis

DNA sequence analysis was accomplished by two different researchers, using the tools from NCBI BLAST (http://blast.ncbi.nlm.nih.gov/Blast.cgi) through alignment with the re- vised Cambridge Reference Sequence (rCRS) of mt-DNA (GenBank accession \# NC 012920) to determine SNP differentiation.

All chromatograms were thoroughly inspected; using the SeqScanner Software (Applied Biosystems) by one researcher and the other used 4Peaks software (v1.8, A. Griekspoor and Tom Groothuis, http://nucleobytes.com/4peaks/index.html). Ambiguous base assignments were corrected manually. Alignment to the rCRS sequence was achieved using Bioedit soft- ware (v7.2.6, Tom Hall, http://www.mbio.ncsu.edu/BioEdit/bioedit.html). Haplogroups were defined using the haplogroup website (http://haplogrep.uibk.ac.at/) and SNP varia- tions were referenced with the phylogenetic tree of global human mt-DNA variation (phylotree.org - mt-DNA tree Build 17 (18 Feb 2016)), to determine haplogroup assignment.

Haplogroup Affiliation

We collected a database of 3831 published HVS-I Haplogroups (with polymorphisms) from Arabia, North Africa, East Africa, West Africa, and the Near 
East that are described in Supplementary Table S2.

Statistical analysis

Statistical calculations and graphs were generated by R software (www.cran-project.org) using FactoMineR (factominer.free.fr) and factoextra (www.sthda.com/english/rpkgs/factoextra) packages for PCA and ggplot2 package (www.ggplot2.org) for graphics.

\section{RESULTS}

Mitochondrial HVS-I sequences were obtained for eleven specimens (73.3\%) and can be classified into different haplotypes: African: L1, L2 and L3, Eurasian: N, H1, $\mathrm{H} 2, \mathrm{~N}, \mathrm{~T} 1, \mathrm{X}$ and $\mathrm{W}$ (Table 1). All are still frequent in current East African, North African, Arab, and Near East populations (Supplementary Table S2).

\section{About Sampling}

The X-Group's 12 samples showed that four (36.36\%) of the 11 specimens presenting a fixed petrous bone were labeled "average" state (Table 1), had their petrous bone detached, and had to be treated as free petrous bones. We found the protocol for skulls having a fixed petrous bone more constraining, as we were required to master the anatomical approach for drilling, temper contact with the bone to avoid overheating the powder (resulting in fragmentation or even destruction of the DNA contained within), and carry out a methodical cleaning of the crankcase and the drilling area to avoid any contamination of the powder.

\section{About DNA amplification}

Four extractions of the total of 15 conducted (26.7\%) were not conclusive and were not sequenced: three samples (MIS-33, MIS-122 and MIS-219 — Table 1) showed a negligible presence of DNA on Agarose gel (probably shorter fragments than our target 145-165 bp).

We were able to obtain DNA amplification in $73.3 \%$ of the cases, with only 4 failures: MIS-33, MIS-122, MIS-219, MIS-151 - Table 1. This failure was with $100 \%$ of the samples labeled "bad" state (MIS-33 and MIS-151 — Table 1) and $66.7 \%$ of the samples labeled "average" state (MIS-122, MIS-219 — Table 1). We did not establish any notable difference

in the success or failure of DNA extraction between the free or fixed petrous bone on the skull.

All the extraction and PCR blanks on the Agarose gel control were negatives, attesting to the absence of contamination during the procedures. We tried the procedure on two teeth samples, and failed to obtain an aDNA extraction and mitochondrial amplification.

\section{About Sanger Sequencing}

All DNA amplifications obtained were successfully sequenced by the Sanger method, only MIS-151 (Table 1) had no conclusive sequencing (repeated twice without success). The references (MIS-TM, MIS-TMT and MIS-TC) were successfully sequenced whereas, on the X-Group's 12 samples, eight were sequenced (66.7\%) and analyzed with the assignment of a haplogroup (Table 1).

\section{General Diversity}


The X-Group set showed some sharing of haplotypes: Four samples (50\% of X-Group set) belonged to the African mega-haplogroup L with two individuals having haplogroup L3 ( $25 \%$ of X-Group set), one individual was labeled L2 and the other one L1. Regarding the Eurasian haplogroups, two individuals shared the $\mathrm{X}$ haplogroup (Table 2). The reference set showed one haplotype H2 (rCRS, no polymorphisms observed on the HVS-I) shared by two individuals (MIS-TM, MIS-TMT - Table 2).

(Here is Table 2)

\section{Haplogroup diversity}

These haplogroups were compared with the database of current mt-DNA haplogroups collected from the literature (Supplementary Table S2). The distribution among the XGroup seemed to be highly diverse, belonging to common Eurasian (N, T1, X) and subSaharan haplogroups (L1-L3), as expected. However, they were less diverse in the reference set; surprisingly they belonged only to common Eurasian haplogroups (H2 and W1).

(Here is Table 3)

\section{Mitochondrial Diversity}

Due to the low number of aDNA sequences, and in order to observe the mt-DNA patterns of the X-Group population within a broad geographical context, we performed a Principal Component Analysis (PCA) based on the frequencies (Table 3) from the literature cited (Supplementary Table S2)(Figure 4). 
bioRxiv preprint doi: $h t t p s: / / d o i . o r g / 10.1101 / 2020.04 .02 .021717$; this version posted April 3, 2020. The copyright holder for this preprint (which was not certified by peer review) is the author/funder, who has granted bioRxiv a license to display the preprint in perpetuity. It is made available under aCC-BY-NC-ND 4.0 International license.

\section{Scree plot}

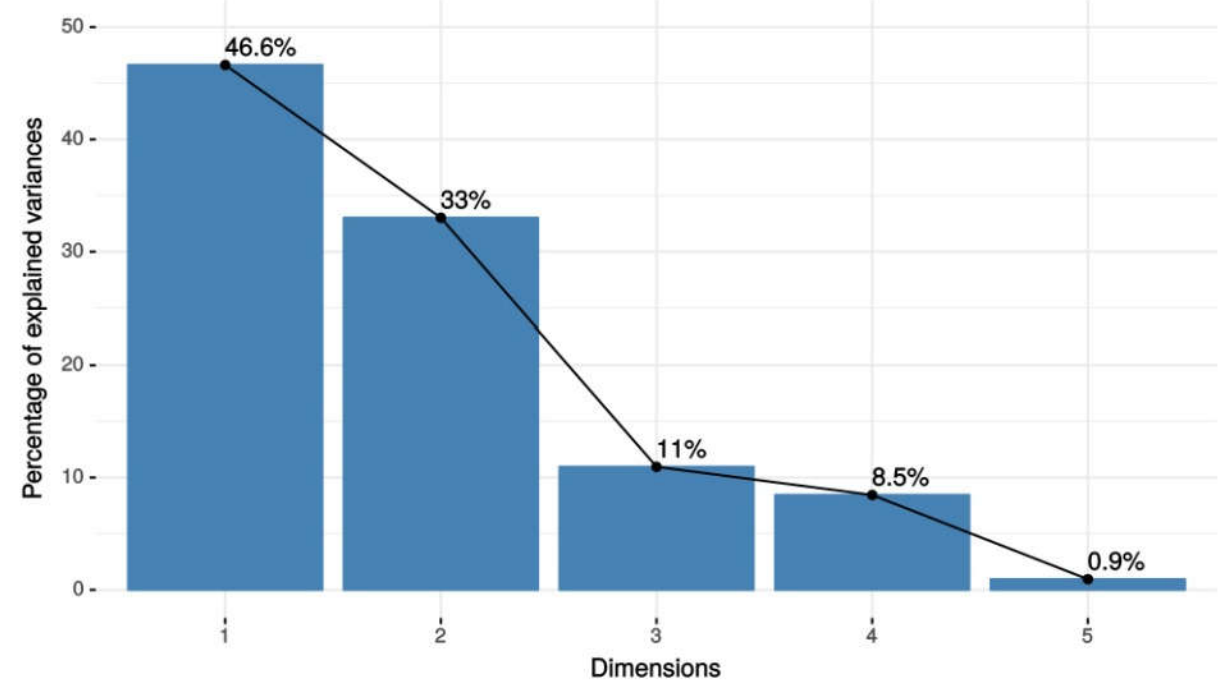

A - Decomposition of the total inertia on the components of the PCA.

The first two dimensions of PCA express $79.64 \%$ of the total dataset inertia ; that means that $79.64 \%$ of the individuals (or variables) cloud total variability is explained by the plane. This percentage is high and thus the first plane represents an important part of the data variability. This value is greater than the reference value that equals $77.4 \%$, the variability explained by this plane is thus significant (the reference value is the 0.95 -quantile of the inertia percentages distribution obtained by simulating 1114 data tables of equivalent size on the basis of a normal distribution).

From these observations, it is probably not useful to interpret the next dimensions.

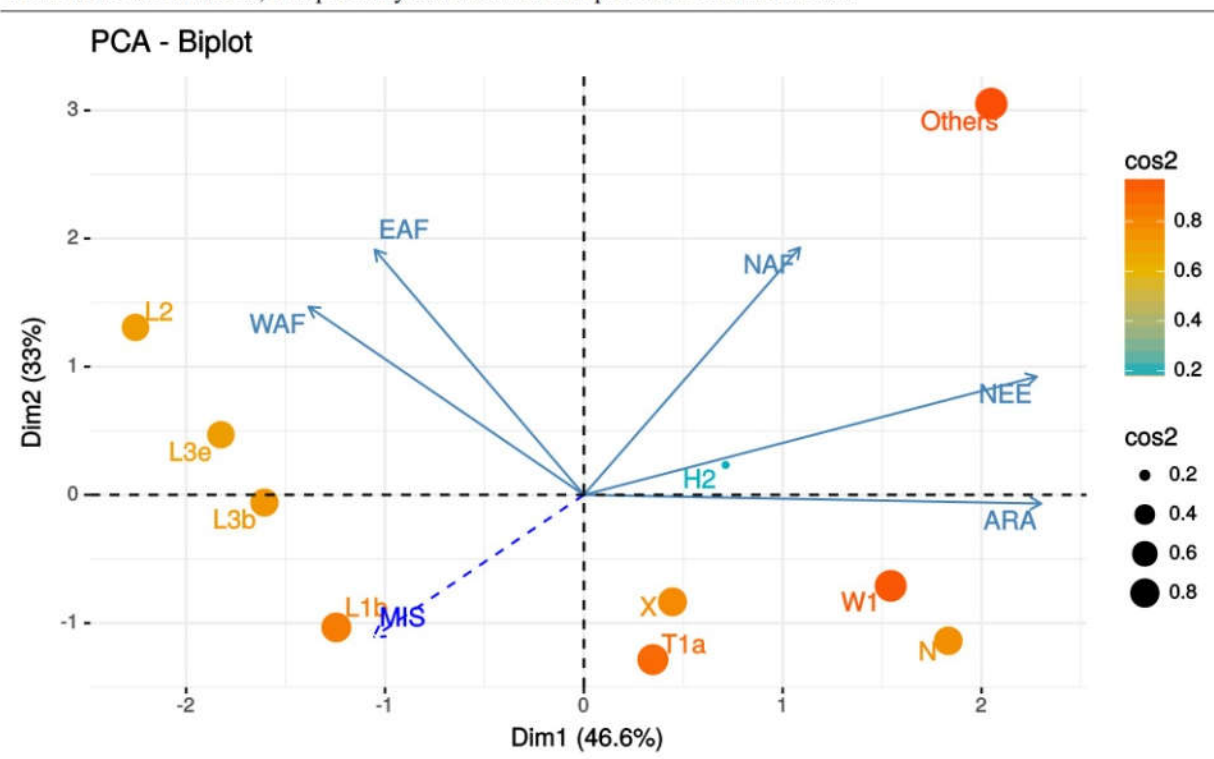

B - Individuals and Variables of the factor map (PCA).

Figure 4: This PCA resumes the Haplogroups diversity and distribution (Table 3) compared to the database collected in literature (Supplementary Table S2). 
Principal components 1 and 2 (Dims 1 and 2 in Fig. 4) account for 79.6\% of the total variation (46.6\% and 33\%, respectively). The two-dimensional pattern displays distinct population clusters: the sub-Saharan populations (East African EAF and West African WAF) located in the most negative portion of axis 1; the Levant region populations (ArabianARA and Near Eastern-NEE) in the upper-right quadrant, respectively; and North Africans (NAF) sandwiched between the sub-Saharan cluster and Levant Region populations, but closer to the latter. If we detail the position of our X-Group (MIS) samples in the overall mitochondrial diversity, the sub-Saharan (EAF and WAF) are most closely related to them whereas those from the Levant region (ARA and NEE) are the furthest away. The North Africans (NAF) are the complete opposite to the X-Group.

The population positions on the PCA Biplot (Figure 4) are explained by the distinction between African and Eurasian haplogroups. As expected, sub-Saharan populations are characterized by high frequencies of L lineages (L1b, L2, L3b and L3e) whereas Eurasians are mainly associated with lineages H2, N1, T1a, X and W. Then, East Africans show high frequencies of L3 (L3b and L3e) and L2 lineages, and Near Easterners are mainlyassociated with lineages H2, X, and N1. Finally, the central position of North Africans is explained by higher frequencies of Eurasian lineages with respect to the African haplogroups, the small frequencies of Eurasian and X lineages, and the presence of the $\mathrm{H} 2$ haplogroup.

Overall, the PCA biplot (Figure 4) based on mitochondrial haplogroup frequencies reflects a clear differentiation between the X-Group and non-sub-Saharan groups (ARA, NEE and NAF) but a close relationship between the X-Group and sub-Saharan populations (EAF and WAF).

\section{DISCUSSION}

The purpose of this study was to assess DNA preservation using a range of archaeological skeletal samples from Sudan (Missiminia in Upper Nubia), from the unfavorable conditions of the Saharan biotope, by tracking the X-Group. Here, we discuss aDNA quality, sequencing, and maternal lineage through mt-DNA haplogroups.

\section{Ancient DNA preservation and its quality}

In addition to precautions carried out to prevent contamination, the monitoring and the control of DNA presence and its quality allowed for increasing compliance with the technical procedures adapted to carry out this study.

In our case, we noticed that samples labeled "bad/average" state (visual) corresponded to low DNA presence on Agarose gel, and also to the failure of amplification and/or sequencing procedures (Table 1), as reported by [12]. The control of $2 \%$ Agarose gel prior tosequencing revealed that, the extraction and PCR blanks were free of any contamination. This was confirmed by the absence of DNA after sequencing. The post-treatment by the Sanger sequencing method, by their length and readability (too many $\mathrm{N}$ or non-homogeneous curves and not individualized), allowed us to detect miscoding lesions and make decisions on running another sequencing for the relevant samples. 
The non-negligible role of environmental parameters in the diagenetic processes undergone by DNA in skeletal remains [45], and both mold and soil environments favorable to the proliferation of microorganisms, were very detrimental to bone DNA conservation because more than $97 \%$ of the bone DNA was lost [46]. On the other hand, the extraction method used has been demonstrated to remove on average $64 \%$ of the microbial DNA from bone powder but only $37 \%$ of the endogenous DNA (from the organism under study), increasing the percentage of informative sequences by a factor of two on average [47], and could explain our good success rate for viable aDNA extraction from archaeological materials from this region.

\section{Sequencing}

Haplogroup affiliations and HVS-I sequences were determined for 11 subjects from Missiminia necropolis, only eight subjects were identified being from the X-Group. Two subjects (MIS-3/1 and MIS-309B - Table 2) were affiliated with the $X$ haplogroup, even if a researcher (AMIS-R03 — Supplementary Table S1) on the sub-Haplogroup X1'3 caused a possible contamination which is not excluded without the results of the HVS-II region which may or may not invalidate this possibility. This would require using Next Generation Sequencing (NGS) to distinguish between ancient and modern DNA. On these two subjects, we should reserve discussion of the results.

Three subjects (MIS-33, MIS-122 and MIS-219. Table 1) showed a negligible presence of DNA on Agarose gel control, an indication of the availability of DNA fragments below our target of 145-165 bp [44]. This aDNA could possibly be obtained through NGS technology, more suited for short fragments, 40 to $90 \mathrm{bp}[48,49]$.

\section{mt-DNA Haplotyping (Maternal Lineage)}

By identifying the affiliation of the haplogroups and their comparison with the cumulative data from the literature (Supplementary Table 1), we can discuss each haplogroup to verify hypotheses on the X-Group origins. We found an influx of subSaharan African ancestry after the Meroitic Period, which corroborates the findings of Schuenemann et al. (2017) [50]. L1b and L2 haplogroups are mostly present in West Africa, respectively at $11.4 \%$ and $51.8 \%$ [51], and also present in North Africa [52-55]. The presence of L1b in the X-Group seems to be due to genetic flow from West to East Africa probably via the nomadic tribes, Berbers in northern Africa $[52,53]$ and Tuareg in the Sahara [55]. While the presence of L2, in the X-Group, seems to be part of its equivalent presence in West and East Africa with shared genetic matches with North Africa [56].

L $3 \mathrm{~b}$ and L3e haplogroups are mostly present in East Africa, respectively at $20.7 \%$ and 26.8\%, mainly in Sudan [57] and in Ethiopia [58, 59], thus, that they are within the XGroup is possible evidence of this in situ evolution, comprising the possibility of a southsouth exchange for L3b or an east-west exchange for L3e [56, 60-62].

$\mathrm{N}, \mathrm{T} 1 \mathrm{a}$ and $\mathrm{X}$ haplogroups are mostly present in Arabia and the Near East, respectively at $25.5 \%, 11.5 \%$, and $10.0 \%$, and still present in North Africa at less than $1.8 \%$ [63]. Without minimizing the question of probable unrecognized contamination (Researcher AMIS-R03 Supplementary Table 1), the presence of this haplogroup X, like T1a and N haplogroups in 
the X-Group, suggests the possible exchange with North Africa and the Levant region (Near East).

Haplogroups W1 and $\mathrm{H} 2$ were not found in the X-Group, just in the reference set respectively still present at around $18 \%$ in Arabia and the Near East and almost $25 \%$ in North Africa [52]. The presence of this haplogroup in the Christian reference (MIS-TC) qualified as Asian, and could suggest by its confirmed presence in Ethiopia [59] an in-situ sub-

Saharan exchange. As for the X haplogroup, the presence of this haplogroup $\mathrm{H}(\mathrm{H} 2-$ rCRS) within the reference set (MIS-TM, MIS-TMT - Table 2) corroborates the possible exchange with North Africa and the Levant region (Near East). This also suggests a possible genetic continuity between the Meroitic (MIS-TM) and Late Meroitic (MIS-TMT), which some authors $[17,18]$ had proposed from an anthropological point of view, as opposed to the archaeological view point of these two sets uniting under the common name of Meroitic.

About the PCA Biplot (Figure 4): Could the significant negative correlation between the $\mathrm{X}$-Group and the North Africans (NAF) possibly be a Mediterranean Break effect on the XGroup? We could not make any clear statement about that as we have a small number of samples and aDNA sequences.

This study on 15 samples (petrous bones) from Nubia, Missiminia necropolis (350 B.C.E to 1400 C.E.), leads us to verify an essential question about the optimal analysis of aDNA on samples from the Nile-Saharan environment. Although the Saharan climate is detrimental to the preservation of DNA, and whilst it is associated with the disadvantages of moisture and salinity (on bone and DNA) that could be added by proximity to the Nile in our study, we were able to extract aDNA (mt-DNA), amplify it and then sequence it successfully on 11 samples (73.3\% success rate), and track the maternal lineage of the XGroup. In general, we observed that "bad/average" visual state correlates to failure in biomolecular procedures, as reported in the literature [12]. However, the study lead us to rethink and optimize new perspectives such as the use of NGS technology to access shorter fragments (40 to $90 \mathrm{bp}$ ) while reconstructing whole genomes (mt-DNA, autosomal and Ychromosomes) that allow new interpretations, integrating the measurement of the quality of the DNA with a bio-analyzer and the massive sequencing at high bit rate, genotyping, validating the presence of modern DNA, the quality of the old DNA obtained, and rebuild phylogenies and phylogeographies based on notions of kinship or even on regional movements of populations. We answered the question of X-Group origins and validated the thesis of an in situ micro- evolution from African local-south and local-east exchanges with more admixture and a more open society than expected towards the Levant region (Near/Middle East) and North Africa as found on haplogroups analysis. However, a more detailed study on a larger sample would be required to assess these statements based on sampling subjects from 300 specimens, with 36 of X-Group and 27 of the pre-Meroitic period found in our collection.

\section{CONCLUSION}

Our tracking of the X-Group of the necropolis of Missiminia (Upper Nubia - Sudan, 350 B.C.E to 1400 C.E) via the mt-DNA haplogroups (Sanger sequencing method) allowed us to test hypotheses about their origins, to validate the feasibility of an aDNA study on 
petrous bones from a Saharan climate with a humid contribution via the Nile (the most unfavorable hot and humid milieu for DNA preservation), and to confirm endogenous DNA protected from climatic variances within the petrous bone.

Our analysis of 15 samples (petrous bones) from the Missiminia necropolis, answered our questions:

- Yes, it is possible to obtain well conserved aDNA on petrous bones from hot and humid environments (we obtained a 73.3\% success rate).

- No, there is no notable difference between free and fixed petrous bone. Moreover, we do not demonstrate the significance of such a difference. (This could also be done within another experimental design).

- The maternal part of the X-Group origins history suggested a more diverse model society than expected, based on Sub-Saharan with Eurasiatic admixture, from Levant and North Africa (to be confirmed by a further study including more samples and a different experimental design).

Our study shows that paleogenetic studies on around 2000-year-old skeletons, from Saharantype environments (even when coupled with the high humidity of the Nile), are feasible on petrous bones free or fixed to the skull. Strict rules to avoid contamination and the conduct and follow-up of technical procedures for mt-DNA via the Sanger method sequencing. The transition to Next Generation Sequencing (NGS) technology should improve the detection of shorter DNA strands and their sequencing in complete genomes on ancient skeletal remains from hot and humid environments.

\section{ACKNOWLEDGEMENTS}

We are very grateful to the AMIS lab team, Toulouse, France for their helpful discussion and comments during the preparation of the manuscript, and to Ryan Schmidt (Ron Pinhasi Lab, UCD, and Ireland) for his helpful discussion and comments about bioinformatics and methodology on the Sanger method and analysis. The present version greatly benefited from the comments provided by the Editors and two anonymous reviewers.

\section{AUTHOR CONTRIBUTIONS}

Conceptualization: Yahia Mehdi Seddik CHERIFI.

Formal analysis: Yahia Mehdi Seddik CHERIFI, Selma AMRANI.

Investigation: Yahia Mehdi Seddik CHERIFI.

Methodology: Yahia Mehdi Seddik CHERIFI, Selma AMRANI.

Visualization: Yahia Mehdi Seddik CHERIFI, Selma AMRANI.

Writing — original draft: Yahia Mehdi Seddik CHERIFI, Selma AMRANI.

Writing — review \& editing: Yahia Mehdi Seddik CHERIFI. 


\section{CONFLICT OF INTEREST}

The authors have none to declare.

\section{References}

[1] C. Anderung, P. Persson, A. Bouwman, R. Elburg, A. Götherström, Fishing for ancient dna, Forensic Science International: Genetics 2 (2) (2008) 104-107.

[2] C. D. Sarkissian, M. E. Allentoft, M. C. Avila-Arcos, R. Barnett, P. F. Campos, E. Cappellini, L. Orlando, Ancient genomics, Philosophical Transactions of the Royal Society B: Biological Sciences 370 (1660) (2014) 20130387-20130387.

[3] N. Rohland, M. Hofreiter, Ancient dna extraction from bones and teeth, Nature Protocols 2 (7) (2007) 17561762.

[4] J. Burger, S. Hummel, B. Herrmann, W. Henke, Dna preservation: A microsatellite-dna study on ancient skeletal remains, Electrophoresis 20 (8) (1999) 1722-1728.

[5] T. D. Torres, J. E. Ortiz, F. J. Llamas, L. Canoira, R. Juliá, M. J. García-Martínez, Bear dentine aspartic acid racemization analysis: a proxy for the dating of pleistocene cave infills, Archaeometry 44 (3) (2002) 417-426.

[6] C. M. Nielsen-Marsh, R. E. Hedges, Patterns of diagenesis in bone i: The effects of site environments, Journal of Archaeological Science 27 (12) (2000) 1139-1150.

[7] E. M. Schotsmans, N. Márquez-Grant, S. Forbes, Taphonomy of human remains: forensic analysis of the dead and the depositional environment (2017).

[8] R. Bollongino, A. Tresset, J. D. Vigne, Environment and excavation: Pre-lab impacts on ancient dna analyses, ComptesRendusPalevol 7 (2-3) (2008) 91-98.

[9] R. E. M. Hedges, A. R. Millard, Bones and groundwater: Towards the modelling of diagenetic processes, Journal of Archaeological Science 22 (2) (1995) 155-164.

[10] M. W. Pedersen, S. Overballe-Petersen, L. Ermini, C. D. Sarkissian, J. Haile, M. Hellstrom, E. Willerslev, Ancient and modern environmental dna, Philosophical Transactions of the Royal Society B: Biological Sciences 370 (1660) (2015) 20130383.

[11] C. Gamba, E. Fernández, A. M. López-Parra, E. Arroyo-Pardo, Statistical evaluation of pre-laboratory and laboratory factors that influence dna recovery from archaeological material, Forensic Science International: Genetics Supplement Series 3 (1) (2011) 109-110.

[12] H. B. Hansen, P. B. Damgaard, A. Margaryan, J. Stenderup, N. Lynnerup, E. Willerslev, M. E. Allentoft, Comparing ancient dna preservation in petrous bone and tooth cementum, Plos One 12 (1) (2017) 0170940.

[13] C. L. Fox, mt-DNA analysis in ancient nubians supports the existence of gene flow between subsahara and north africa in the nile valley, Annals of Human Biology 24 (3) (1997) 217-227.

[14] V. Francigny, H. Hollund, A. D. Voogt, E. Altena, P. D. Knijff, C. Fallet, Limits of ancient dna extraction from teeth: The case of sudanese nubia, NyameAkuma 79 (2013) 13-29.

[15] K. A. Sirak, D. G. Bradley, C. Gamba, E. R. Jones, R. Pinhasi, G. J. Armelagos, Ancient dna analysis of an infant from sudanese nubia (ca 500-1400 ce), In American Journal of Physical Anthropology (Vol 153 (2014) 240-241, wiley-Blackwell 111 River St, Hoboken 07030-5774.

[16] M. R. Buzon, A bioarchaeological perspective on egyptian colonialism in nubia during the new kingdom, The Journal of Egyptian Archaeology 94 (2008) 165-181.

[17] E. Crubezy, Caractères discrets et évolution. exemple d'une population nubienne: Missiminia (soudan) (1991).

[18] D. D. Stynder, J. Braga, E. Crubezy, Craniometric evidence for biological continuity between meroitic and post-meroitic populations buried at the necropolis of missiminia, middle nubia, The South African Archaeological Bulletin 64 (190) (2009) 122-129.

[19] S. O. Y. Keita, History in the interpretation of the pattern of p49a,ftaqi rflp y-chromosome variation in egypt: A consideration of multiple lines of evidence, American Journal of Human Biology 17 (5) (2005) 559567. 
[20] G. Lucotte, G. Mercier, Brief communication: Y-chromosome haplotypes in egypt, American Journal of Physical Anthropology 121 (1) (2003) 63-66.

[21] D. J. D. Irish, Population continuity vs. discontinuity revisited: Dental affinities among late paleolithic through christian-era nubians, American Journal of Physical Anthropology 128 (3) (2005) 520-535.

[22] M. M. E. Jans, Histological characterisation of diagenetic alteration of archaeological bone (2005).

[23] M. Pruvost, R. Schwarz, V. B. Correia, S. Champlot, S. Braguier, N. Morel, E. M. Geigl, Freshly excavated fossil bones are best for amplification of ancient dna, Vol. 104, 2007, pp. 739-744.

[24] A. Vila, K. N. Museum, La prospection archéologique de la vallée du nil au sud de la cataracte de dal (nubie soudanaise), in: : La nécropole de Missiminia (Section française de la direction des antiquités du Soudan), Vol. 15, Ed.) (Vols, 1985, pp. 1-1.

[25] General history of africa volume 2: Ancient civilizations of africa (abridged edition), James Currey, London England : Berkeley, Calif. : Paris, 1990.

[26] The meroitic cemetery at berber. recent fieldwork and discussion on internal chronology, Sudan TeXampSymb Nubia 19 (2015) 97-105.

[27] D. N. Edwards, Post-meroitic ('x-group') and christian burials at sesibi, sudanese nubia. the excavations of 1937, The Journal of Egyptian Archaeology 80 (1994) 159-178.

[28] B. G. Trigger, History and settlement in Lower Nubia (First Edition edition). Dept, of Anthropology, Yale University, 1965.

[29] E. Crubezy, N. Telmon, A. Sevin, J. Picard, D. Rougé, G. Larrouy, P. Murail, Microévolution d'une population historique. Étude des caractères discrets de la population de missiminia (soudan, iiie-vie siècle), in: Bulletins et Mémoires de la Société d'anthropologie de Paris, Paris, 1999, pp. 11-1.

[30] G. Billy, La Nécropole de Missiminia. V-Anthropology. Vila, A.(Éd.) La Prospection Archéologique de La Vallée Du Nil, Vol. 15, Au Sud de La Cataracte de Dal, 1985.

[31] P. Iacumin, A. D. Matteo, D. Usai, S. Salvatori, G. Venturelli, Stable isotope study on ancient populations of central sudan: Insights on their diet and environment, American Journal of Physical Anthropology 160 (3) (2016) 498-518.

[32] P. Weschenfelder, Water management by divine benevolence along the nile river: Artificial water reservoirs as pastoral meeting places in the meroitic sudan (ca, in: B. C. . A. D. People (Ed.), Usages and Meanings of Water in a Global Perspective, 2012, p. 350.

[33] D. S. Carlson, D. P. V. Gerven, Diffusion, biological determinism, and biocultural adaptation in the nubian corridor, American Anthropologist 81 (3) (1979) 561-580.

[34] K. Godde, A measure of biological distance in nubians: a look at intrapopulation variation, American JournalofPhysical Anthropology(2005) 106-107.

[35] K. Godde, Who were the meroites? a biological investigation into the nubian post-hiatus group, International Journal of Osteoarchaeology 20 (4) (2010) 388-395.

[36] K. Godde, An examination of the spatial-temporal isolation model in a nilotic population: Variation across space and time in nubians using cranial discrete traits, International Journal of Osteoarchaeology 23 (3) (2013) 324-333.

[37] D. L. Greene, G. H. Ewing, G. J. Armelagos, Dentition of a mesolithic population from wadihalfa, sudan, American Journal of Physical Anthropology 27 (1) (1967) 41-55.

[38] D. P. V. Gerven, The contribution of time and local geography to craniofacial variation in nubia's batn el hajar, American Journal of Physical Anthropology 59 (3) (1982) 307-316.

[39] M. Krings, A. H. Salem, K. Bauer, H. Geisert, A. K. Malek, L. Chaix, M. Stoneking, mt-DNA analysis of nile river valley populations: A genetic corridor or a barrier to migration?, The American Journal of Human Genetics 64 (4) (1999) 1166-1176.

[40] R. Pinhasi, D. Fernandes, K. Sirak, M. Novak, S. Connell, S. Alpaslan-Roodenberg, M. Hofreiter, Optimal ancient dna yields from the inner ear part of the human petrous bone, Plos One 10 (6).

[41] M. T. P. Gilbert, H. J. Bandelt, M. Hofreiter, I. Barnes, Assessing ancient dna studies, Trends in Ecology \& Evolution 20 (10)(2005) 541-544.

[42] E. Willerslev, A. Cooper, Review paper. ancient dna, Proceedings of the Royal Society B: Biological Sciences 272 (1558) (2005) 3-16. 
[43] M. Knapp, A. C. Clarke, K. A. Horsburgh, E. A. Matisoo-Smith, Setting the stage - Building and working in an ancient DNA laboratory, Vol. 194, 2012.

[44] N. Y. Kim, H. Y. Lee, S. J. Park, W. I. Yang, K. J. Shin, Modified midi- and mini-multiplex pcr systems for mitochondrial dna control region sequence analysis in degraded samples, Journal of Forensic Sciences 58 (3) (2013) 738-743.

[45] Adsorption of DNA on biomimetic apatites: Toward the understanding of the role of bone and tooth mineral on the preservation, Vol. 292.

[46] L. Startari, J. N. Benoit, G. Quatrehomme, G. Carle, P. Pognonec, Comparison of extractable dna from bone following six-month exposure to outdoor conditions, garden loam, mold contamination or room storage, Medicine, Science and the Law.

[47] P. Korlevic, T. Gerber, G. M.-T, H. M., S. Nagel, A. Aximu-Petri, M. Meyer, Reducing microbial and human contamination in dna extractions from ancient bones and teeth, Biotechniques 59 (2015) 87-93.

[48] S. Goodwin, J. D. McPherson, W. R. McCombie, Coming of age: ten years of next-generation sequencingtechnologies, Nature Reviews Genetics 17 (6)(2016) 333-351.

[49] L. Orlando, M. T. P. Gilbert, E. Willerslev, Reconstructing ancient genomes and epigenomes, Nature Reviews Genetics 16 (7) (2015) 395-408.

[50] V. Schuenemann, A. Peltzer, B. Welte, W. Pelt, M. Molak, C. Wang, A. Furtwängler, C. Urban,

E. Reiter, K. Nieselt, B. Teßmann, M. Francken, K. Harvati, W. Haak, S. K. Schiffels, J., Ancient egyptian mummy genomes suggest an increase of sub-saharan african ancestry in post-roman periods, Nature Communications 8 (2017) 15694.

[51] G. Primativo, C. Ottoni, G. Biondi, S. Serafino, C. Martínez-Labarga, M. H. D. Larmuseau, O. Rickards, Bight of benin: a maternal perspective of four beninese populations and their genetic implications on the american populations of african ancestry, Annals of Human Genetics 81 (2) (2017) 78-90.

[52] C. Coudray, A. Olivieri, A. Achilli, M. Pala, M. Melhaoui, M. Cherkaoui, J. M. Dugoujon, The complex and diversified mitochondrial gene pool of berber populations, Annals of Human Genetics 73 (2) (2009) 196214.

[53] K. Fadhlaoui-Zid, S. Plaza, F. Calafell, M. B. Amor, D. Comas, A. Bennamar, E. Gaaied, Mitochondrial dna heterogeneity in tunisian berbers, Annals of Human Genetics 68 (3) (2004) 222-233.

[54] K. Fadhlaoui-Zid, L. Rodríguez-Botigué, N. Naoui, A. Benammar-Elgaaied, F. Calafell, D. Comas, Mitochondrial dna structure in north africa reveals a genetic discontinuity in the nile valley, American Journal of Physical Anthropology 145 (1) (2011) 107-117.

[55] C. Ottoni, C. Martínez-Labarga, E. L. Loogväli, E. Pennarun, A. Achilli, F. D. Angelis, O. Rickards, First genetic insight into libyan tuaregs: A maternal perspective, Annals of Human Genetics 73 (4) (2009) 438-448.

[56] A. Rosa, A. Brehm, T. Kivisild, E. Metspalu, R. Villems, Mt-DNA profile of west africa guineans: Towards a better understanding of the senegambia region, Annals of Human Genetics 68 (4) (2004) 340-352.

[57] P. Soares, F. Alshamali, J. B. Pereira, V. Fernandes, N. M. Silva, C. Afonso, L. Pereira, The expansion of mt-DNA haplogroup 13 within and out of africa, Molecular Biology and Evolution 29 (3) (2012) 915927.

[58] A. Boattini, L. Castrì, S. Sarno, A. Useli, M. Cioffi, M. Sazzini, D. Luiselli, mt-DNA variation in east africa unravels the history of afro-asiatic groups, American Journal of Physical Anthropology 150 (3) (2013) 375-385.

[59] T. Kivisild, M. Reidla, E. Metspalu, A. Rosa, A. Brehm, E. Pennarun, R. Villems, Ethiopian mitochondrial dna heritage: Tracking gene flow across and around the gate of tears, American Journal of Human Genetics 75 (5) (2004) 752-770.

[60] D. M. Behar, R. Villems, H. Soodyall, J. Blue-Smith, L. Pereira, E. Metspalu, S. Rosset, The dawn of human matrilineal diversity, The American Journal of Human Genetics 82 (5) (2008) 1130-1140.

[61] A. Salas, M. Richards, T. Fe, M. V. Lareu, B. Sobrino, P. Sánchez-Diz, A. Carracedo, The making of the african mt-DNA landscape, American Journal of Human Genetics 71 (5) (2002) 1082-1111.

[62] P. Soares, L. Ermini, N. Thomson, M. Mormina, T. Rito, A. Röhl, M. B. Richards, Correcting for purifying selection: An improved human mitochondrial molecular clock, The American Journal of 

made available under aCC-BY-NC-ND 4.0 International license.

Human Genetics 84 (6) (2009) 740-759.

[63] Bekada, R. Fregel, V. M. Cabrera, J. M. Larruga, J. Pestano, S. Benhamamouch, A. M. González, Introducing the algerian mitochondrial dna and y-chromosome profiles into the north african landscape, Plos One 8 (2) (2013) 56775. 


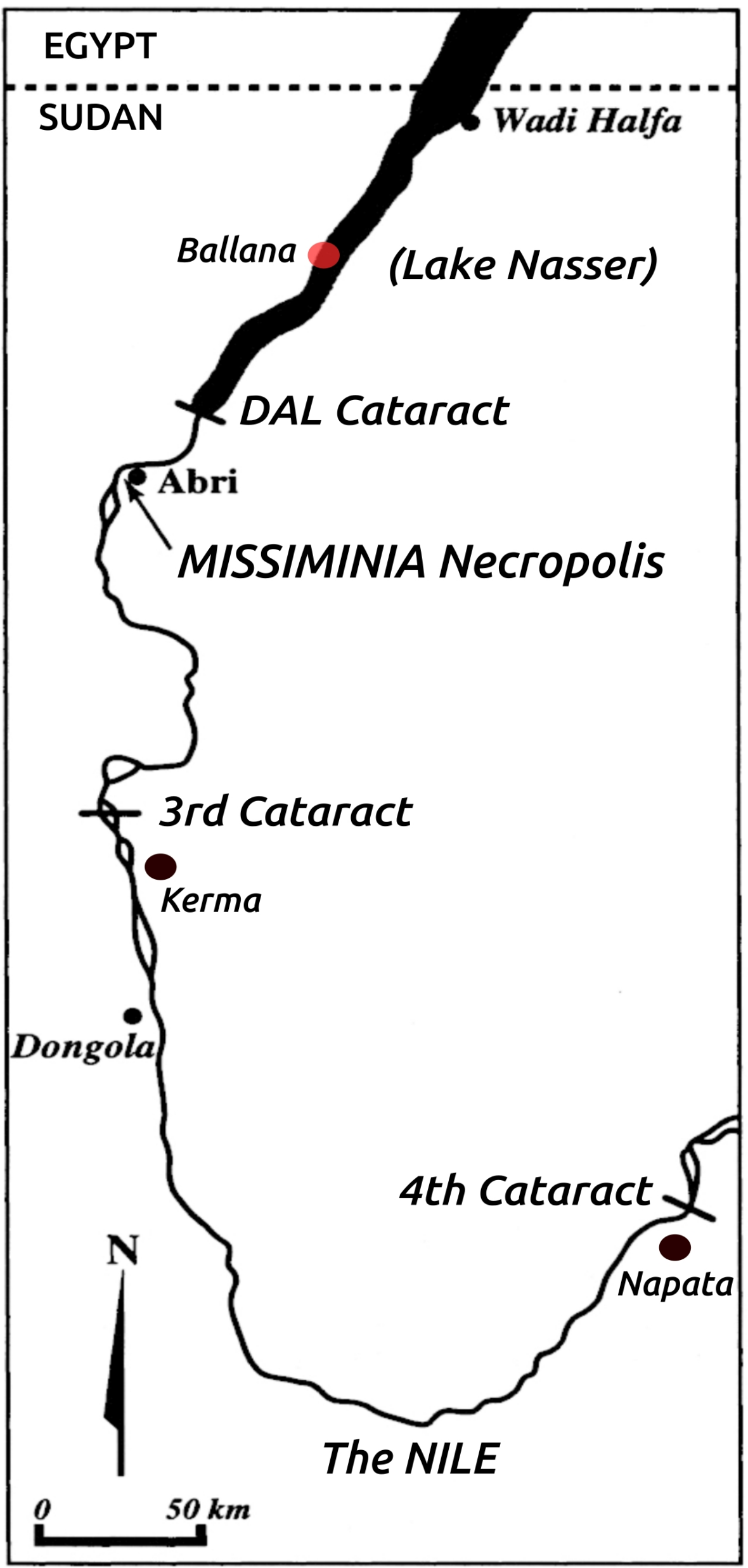


Mediterranean

break?

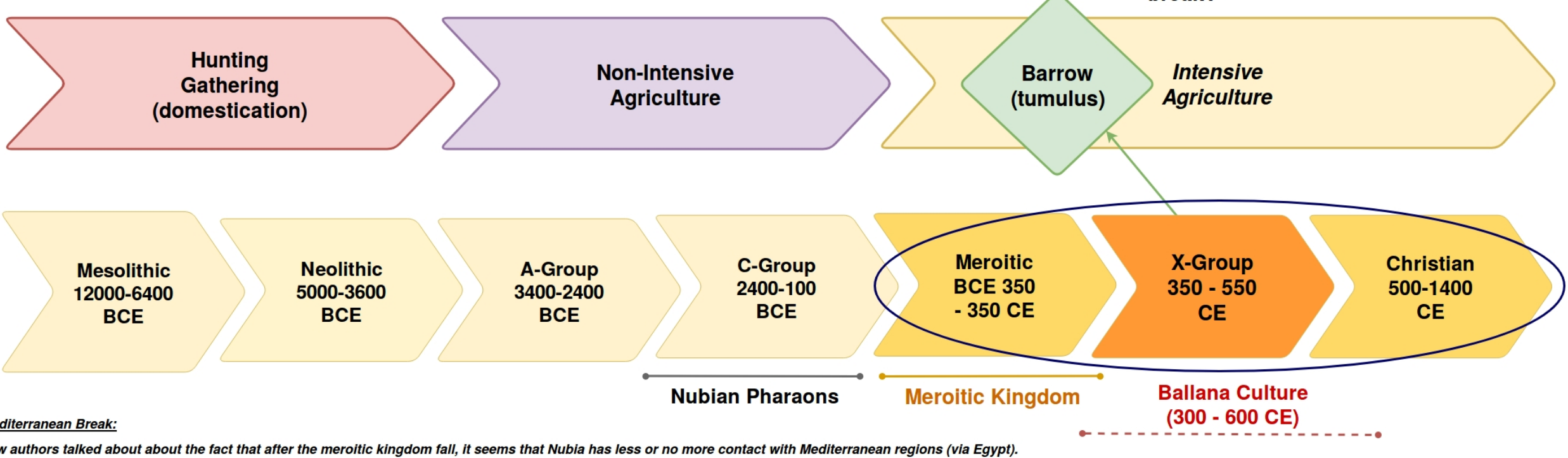

Few authors talked about about the fact that after the meroitic kingdom fall, it seems that Nubia has less or no more contact with Mediterranean regions (via Egypt)

Was that a choice from the Roman empire? (no historical evidence found about this). 

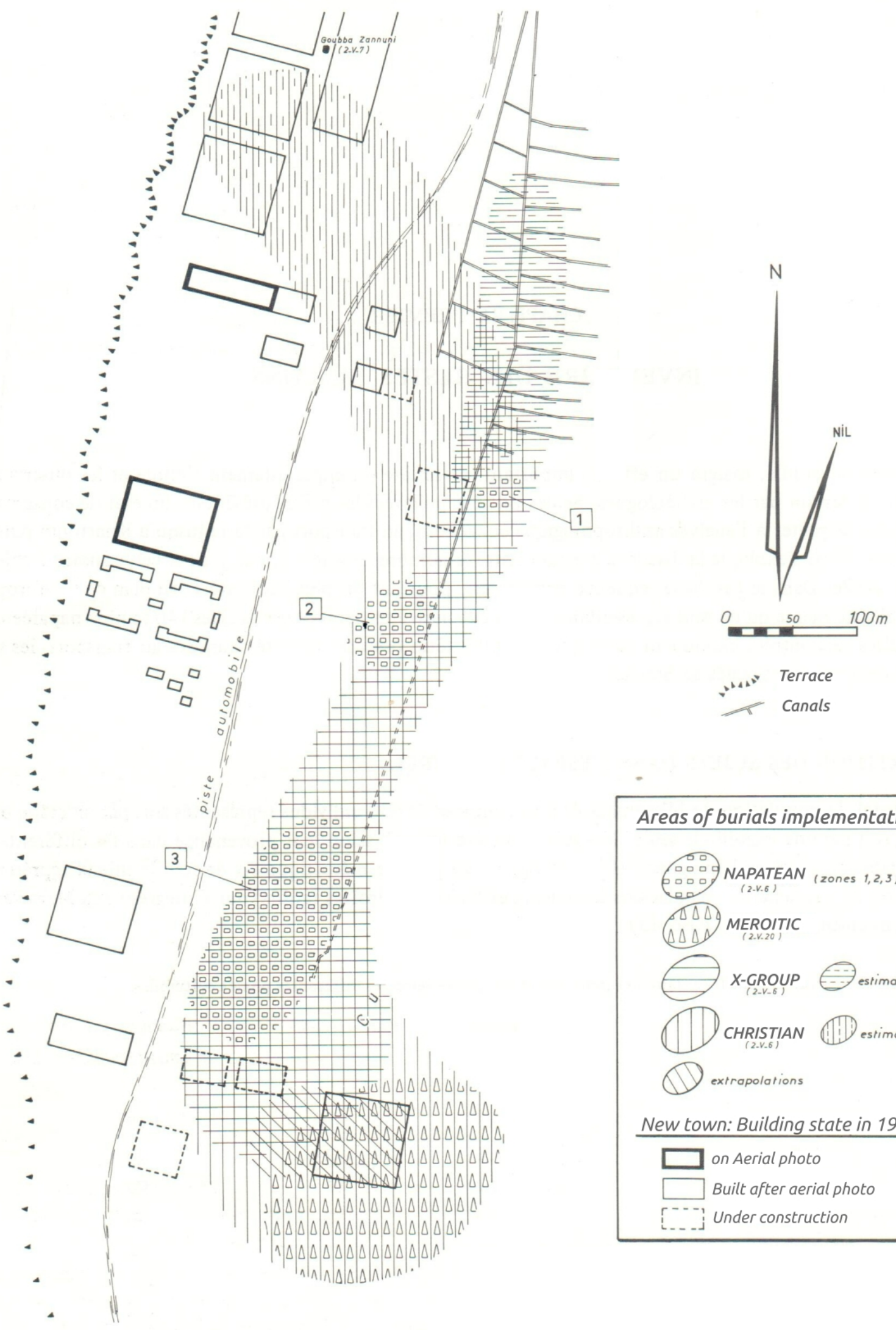

Areas of burials implementation

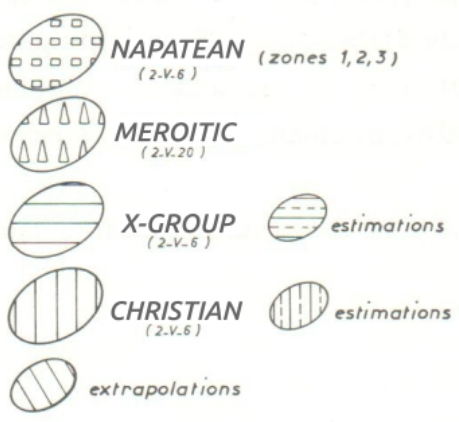

New town: Building state in 1975

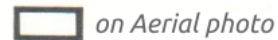

Built after aerial photo

Under construction 
bioRxiv preprint doi: https://doi.org/10.1101/2020.04.02.021717; this version posted April 3, 2020. The copyright holder for this preprint (which was not certified by peer review) is the author/funder, who has granted bioRxiv a license to display the preprint in perpetuity. It is made available under aCC-BY-NC-ND 4.0 International license.

Table 1

Samples details and results of mt-DNA (HVS-I) : 15 samples from Missiminia (X-Group and References)

X-GROUP: 12 samples

\begin{tabular}{ccccccccc}
\hline & & \multicolumn{3}{c}{$\begin{array}{c}\text { Anthropological } \\
\text { Details }\end{array}$} & Petrous Bone & \multicolumn{2}{c}{ Results of mt-DNA (HVS-I) } \\
\hline Sample & Code Lab & Sex & $\begin{array}{c}\text { Age } \\
\text { (Y) }\end{array}$ & $\begin{array}{c}\text { Barrow } \\
\text { (diameter } \\
\text { M) }\end{array}$ & State & Type & $\begin{array}{c}\text { DNA amplification } \\
\text { (Agarose gel 2\%) }\end{array}$ & $\begin{array}{c}\text { Sanger } \\
\text { Sequencing }\end{array}$ \\
\hline 2V6/83 & MIS-83 & F & $20-30$ & 18 & $* * *$ & Fixed & Ok (Twice) & Ok \\
\hline 2V6/33 & MIS-33 & M & $40-50$ & 17 & $*$ & Free & $\begin{array}{c}\text { Negligible (DNA } \\
\text { fragments }<150 \mathrm{bp})\end{array}$ & - \\
\hline 2V6/93 & MIS-93 & F & $30-40$ & 10 & $* * *$ & Fixed & Ok & Ok \\
\hline 8-B-34/3/1 & MIS-3/1 & F & $30-40$ & 10 & $* * *$ & Fixed & Ok & Ok \\
\hline 2V6/122 & MIS-122 & M & $30-40$ & 7 & $* *$ & Fixed & $\begin{array}{c}\text { Negligible (DNA } \\
\text { fragments }<150 b p)\end{array}$ & - \\
\hline 2V6/219 & MIS-219 & F & $30-40$ & 7 & $* *$ & Free & $\begin{array}{c}\text { Negligible (DNA } \\
\text { fragments }<150 b p)\end{array}$ & - \\
\hline 2V6/C & MIS-C & M & $50-60$ & - & $* * *$ & Free & Ok & Ok \\
\hline 2V6/171 & MIS-171 & M & $20-25$ & - & $* *$ & Fixed & Ok (Twice) & Ok \\
\hline 2V6/151 & MIS-151 & F & $18-20$ & - & $*$ & Free & Smear & - \\
\hline 2V6/309B & MIS-309B & F & $30-40$ & - & $* * *$ & Fixed & Ok & Ok \\
\hline 2V6/466 & MIS-466 & M & $20-25$ & - & $* * *$ & Fixed & Ok & Ok \\
\hline 2V6/474 & MIS-474 & F & $20-30$ & - & $* * *$ & Fixed & Ok & Ok \\
\hline
\end{tabular}

REFERENCES: 03 samples, each from other groups (Meroitic, Late Meroitic and Christian)

\begin{tabular}{ccccccccc}
\hline & & \multicolumn{3}{c}{$\begin{array}{c}\text { Anthropological } \\
\text { Details }\end{array}$} & Petrous Bone & \multicolumn{2}{c}{ Results of mt-DNA (HVS-I) } \\
\hline Sample & Code Lab & Sex & $\begin{array}{c}\text { Age } \\
\text { (Y) }\end{array}$ & Group & State & Type & $\begin{array}{c}\text { DNA amplification } \\
\text { (Agarose gel 2\%) }\end{array}$ & $\begin{array}{c}\text { Sanger } \\
\text { Sequencing }\end{array}$ \\
\hline 2V20/263/1 & MIS-TM & F & $40-50$ & Meroitic & $* * *$ & Fixed & Ok & Ok \\
\hline 2 V20/214/2 & MIS-TMT & M & $18-25$ & $\begin{array}{c}\text { Late } \\
\text { Meroitic }\end{array}$ & $* * *$ & Fixed & Ok & Ok \\
\hline 2V6/135/2 & MIS-TC & M & $20-30$ & Christian & $* * *$ & Fixed & Ok & Ok \\
\hline
\end{tabular}

Note:

Anthropological data are issued from the osteometrical study done by Billy 1985.

'State': visual and tactile inspection, is scored '*' (bad), '**' (average) or '***' (good).

'Type': petrous bone free or fixed on the cranium.

'Operated': teeth has undergone the sampling technique.

The sample 8-B-34/3/1 is not from MISSIMINIA necropolis, coming from El Behel cemetery.

Four samples are not sequenced: MIS-33, MIS-122, MIS-219 and MIS-151.

Three samples $(2 \mathrm{V6} / 33,2 \mathrm{V6} / 122$ and $2 \mathrm{V6} / 219)$ are barely visible on Agarose gel (DNA fragments < 150bp).

Two samples (2V6/83 and 2V6/171) have been amplified twice on some fragments M13 for MIS-83 and M11 and M14 for MIS-171 that were silent. 
Table 2

Haplogroups identification results (Alignment to the rCRS sequence) on HVS-I.

\begin{tabular}{lclc}
\hline Code Lab & Range & \multicolumn{1}{c}{ Polymorphisms } & Haplogroup \\
\hline MIS-83 & 16009-16391 & 16126C 16187T 16189C 16223T 16264T 16270T 16278T & L1b \\
\hline MIS-93 & $16009-16391$ & 16126C 16187T 16189C 16223T 16278T & L2 \\
\hline MIS-3/1 & $16009-16391$ & 16182C 16183C 16189C 16223T 16278T & X \\
\hline MIS-C & $16009-16391$ & 16126C 16163G 16186T 16189C 16238T 16311C & T1a \\
\hline MIS-171 & $16009-16391$ & 16182C 16183C 16189C 16223T 16278T 16362C & L3b \\
\hline MIS-309B & $16009-16391$ & 16189C 16223T 16278T & X \\
\hline MIS-466 & $16009-16391$ & 16033T 16037G 16223T 16278T & L3e \\
\hline MIS-474 & $16009-19391$ & 16037G 16223T 16278T 16299T & N \\
\hline MIS-TM & $16034-16385$ & rCRS (no polymorphism) & H2 \\
\hline MIS-TMT & $16034-16365$ & rCRS (no polymorphism) & H2 \\
\hline MIS-TC & $16024-16391$ & 16037G 16223T 16292T 16295Y & W1 \\
\hline
\end{tabular}


Table 3

Haplogroup frequencies (\%) (based on groups of populations), modern ( $\mathrm{n}=3831)$ populations used in the population genetic analyses.

\begin{tabular}{|l|c|c|c|c|c|c|c|c|c|c|c|c|}
\hline Population & Code & $\mathbf{n}$ & L1b & L2 & L3b & L3e & N & T1a & X & H2 & W1 & Others \\
\hline Arabia & ARA & 365 & $\mathbf{1 . 3 7}$ & $\mathbf{3 . 5 6}$ & $\mathbf{1 . 6 4}$ & $\mathbf{1 . 1 0}$ & $\mathbf{2 5 . 4 8}$ & $\mathbf{1 0 . 6 8}$ & $\mathbf{9 . 5 9}$ & $\mathbf{8 . 7 7}$ & $\mathbf{1 9 . 4 5}$ & 18.36 \\
\hline Near-East & NEE & 628 & $\mathbf{0 . 1 6}$ & $\mathbf{0 . 6 4}$ & $\mathbf{1 . 1 1}$ & $\mathbf{0 . 9 6}$ & $\mathbf{1 7 . 3 6}$ & $\mathbf{1 1 . 4 6}$ & $\mathbf{1 0 . 6 7}$ & $\mathbf{9 . 7 1}$ & $\mathbf{1 6 . 2 4}$ & 31.69 \\
\hline North-Africa & NAF & 1676 & $\mathbf{4 . 1 8}$ & $\mathbf{9 . 0 1}$ & $\mathbf{3 . 5 8}$ & $\mathbf{5 . 3 7}$ & $\mathbf{1 . 7 9}$ & $\mathbf{1 . 1 9}$ & $\mathbf{8 . 9 5}$ & $\mathbf{2 4 . 4 6}$ & $\mathbf{9 . 2 5}$ & 32.22 \\
\hline $\begin{array}{l}\text { East-Africa } \\
\text { West-Africa }\end{array}$ & EAF & 969 & $\mathbf{1 . 7 5}$ & $\mathbf{1 6 . 3 1}$ & $\mathbf{2 0 . 7 4}$ & $\mathbf{2 6 . 8 3}$ & $\mathbf{0 . 5 2}$ & $\mathbf{1 . 0 3}$ & $\mathbf{1 . 0 3}$ & $\mathbf{3 . 4 1}$ & $\mathbf{0 . 3 1}$ & 29.41 \\
\hline & WAF & 193 & $\mathbf{1 1 . 4 0}$ & $\mathbf{5 1 . 8 1}$ & $\mathbf{8 . 2 9}$ & $\mathbf{1 0 . 8 8}$ & $\mathbf{0 . 0 0}$ & $\mathbf{0 . 0 0}$ & $\mathbf{0 . 0 0}$ & $\mathbf{0 . 0 0}$ & $\mathbf{0 . 0 0}$ & 17.62 \\
\hline & Total & $\mathbf{3 8 3 1}$ & $\mathbf{3 . 0 0}$ & $\mathbf{1 1 . 1 2}$ & $\mathbf{7 . 5 7}$ & $\mathbf{7 . 8 3}$ & $\mathbf{5 . 4 8}$ & $\mathbf{3 . 2 1}$ & $\mathbf{5 . 6 6}$ & $\mathbf{1 3 . 9 9}$ & $\mathbf{8 . 6 4}$ & 33.49 \\
\hline & & & & & & & & & & & & \\
\hline $\begin{array}{r}\text { Missiminia } \\
\text { X-Group only }\end{array}$ & MIS & $\mathbf{8}$ & $\mathbf{1 2 . 5 0}$ & $\mathbf{1 2 . 5 0}$ & $\mathbf{1 2 . 5 0}$ & $\mathbf{1 2 . 5 0}$ & $\mathbf{1 2 . 5 0}$ & $\mathbf{1 2 . 5 0}$ & $\mathbf{2 5 . 0 0}$ & $\mathbf{0 . 0 0}$ & $\mathbf{0 . 0 0}$ & 0.00 \\
\hline
\end{tabular}

Note:

Litterature references are listed in Supplementary Table S2 (sources with literature cited details).

'Others' could include sub-clads from L1, L2 or L3, H1, and also from other haplogroups that were not

listed within the X-Group (LO, L4, M, I, HV, ...). 